Cornell Law Library

Scholarship@Cornell Law: A Digital Repository

Cornell Law Faculty Publications

Faculty Scholarship

$10-1959$

\title{
The Supreme Court and the Decline of State Power
}

Roger C. Cramton

Cornell Law School, rcc10@cornell.edu

Follow this and additional works at: http://scholarship.law.cornell.edu/facpub

Part of the Constitutional Law Commons, Courts Commons, and the State and Local

Government Law Commons

\section{Recommended Citation}

Cramton, Roger C., "The Supreme Court and the Decline of State Power" (1959). Cornell Law Faculty Publications. Paper 1258.

http://scholarship.law.cornell.edu/facpub/1258

This Article is brought to you for free and open access by the Faculty Scholarship at Scholarship@Cornell Law: A Digital Repository. It has been accepted for inclusion in Cornell Law Faculty Publications by an authorized administrator of Scholarship@Cornell Law: A Digital Repository. For more information, please contact jmp8@cornell.edu. 


\title{
THE SUPREME COURT AND THE DECLINE OF STATE POWER
}

\author{
ROGER C. CRAMTON \\ University of Chicago Law School
}

\begin{abstract}
A DECADE ago a foreign observer of our system of government characterized the American state as "a province in which it is not difficult to distinguish what may perhaps be termed the vestigial remains of sovereign power."1 Harold Laski was not disappointed that this was so; he had previously argued that federalism was obsolete under modern conditions:

... The epoch of federalism is over. . . It is insufficiently positive in character; it does not provide for sufficient rapidity of action; it inhibits the emergénce of the necessary standards of uniformity; it relies upon compacts and compromises which take insufficient account of the urgent category of time; it leaves the backward areas a restraint, at once parasitic and poisonous, on those which seek to move forward; at least, its psychological results, especially in an age of crisis, are depressing to a democracy that needs the drama of positive achievement to retain its faith. ${ }^{2}$
\end{abstract}

Many Americans who might have agreed with Laski's factual statement that the expanding powers of the national government had reduced the states to administrative provinces did not share his satisfaction. They believed that our Union was designed as a Union of states; that government, which at best is a necessary evil, should remain close to the people; and that the process of centralization threatened not only to obliterate the constitutional structure but to usurp the liberties of the people. ${ }^{3}$

Even the most casual observer of the events of the last half-century recognizes an element of truth in these opposing viewpoints. The clumsy Union of sovereign states envisioned by John Calhoun, beset with centrifugal pressures and wracked with internal disputes, could not deal with the intricate social and economic problems of our interdependent society or cope with the menace of modern totalitarianism. On the other hand, the accelerating march of power to Washington cannot be observed without misgiving by those who-unlike Mr. Laski-treasure the rewards of local control and the tolerant diversity of American life. Is there no escape from this dilemma?

\footnotetext{
${ }^{1}$ H. J. Laski, The American Democracy 138 (1948).

'Laski, The Obsolescence of Federalism, 98 New Republic 367 (May 3, 1939).

'J. J. Kilpatrick, The Sovereign States (1957), contains a spirited statement of these views.
} 
It is beyond dispute that there has been a substantial shift in the weight and importance of the federal and state governments. The expansion of federal authority and responsibility is obvious to all. Equally obvious, but often overlooked, is the expansion of state and local government. The states have neither withered away nor been transformed into field offices of the national government; they too have become more powerful agencies of government and have retained a large degree of independence, initiative and responsibility. ${ }^{4}$ And much of the expansion in federal power has not been at the expense of the states, at least in a constitutional sense. The recurring crises of war and the continuing dangers of an uneasy peace, matters which were intended to be dealt with by the national government, have been responsible for the larger part of the increased federal activity. ${ }^{5}$ Thus the celebrated attrition of state power is in part, at least, an illusion. The paradox, as Leonard White has said, is that "the states have gained strength absolutely, and at the same time lost status relatively." power in the context of the constitutional division of powers between the states and the nation. Constantly in the background will be basic issues: the rightful position of the states in the federal system; the causes of the decline of state power; and the ultimate responsibility of the people for the preservation of the enduring values of federalism.

Throughout our history, the proper balance of power between the states and the nation has been a matter of constitutional and political controversy. In recent years the charge that the federal government has encroached on the rightful position of the states has been increasingly heard. Often the blame for the alleged encroachment is placed on the engulfing tendencies of the federal bureaucracy or on the efforts of the communist conspiracy to undermine our system of government. But the charge, especially when made by lawyers, has usually been directed at the Supreme Court of the United States. Although the terms of the indictment vary, the usual ingredients are: (1) a denial of the legitimacy of the Supreme Court's power to review state judgments in cases involving the constitutionality of state legislation or state conduct; (2) an attack on the Court's exercise of this power, even assuming it legitimately to exist; and (3) a charge that the Court has abdicated its prime role of confining the national government to the powers delegated it by the Constitution. These are large matters, incapable of exact summary. Nevertheless, an attempt will be made to evaluate these charges and to assess the responsibility of the Supreme Court for the decline of state power.

\footnotetext{
- The expansion of federal activity and the corresponding increase in the activity of the states is well summarized in the Report of President Eisenhower's Commission on Intergovernmental Relations: A Report to the President for Transmittal to Congress (1955) (hereafter cited as Report).

${ }^{5}$ Expenditures for national defense, war, diplomacy and foreign aid now exceed all other expenditures of all governments in this country put together. Report, at 20.

${ }^{\circ} \mathrm{L}$. D. White, The States and the Nation 32 (1953).
} 


\section{The Constitutional Basis for the Supreme Court's Power To Umpire the Federal System}

Any federal system requires an institution to determine conflicts of authority between the nation and its constituent states. In our system the Supreme Court has exercised this function from the beginning, and there has been general acquiescence in the propriety of its doing so. Yet throughout our history recurrent attacks on the legitimacy of the Supreme Court's power to umpire the federal system have been made by groups dissatisfied with particular exercises of this power.

The extreme states' rights position of John C. Calhoun provides the most elaborate-but not the earliest-intellectual support for these attacks. His position rested on the basic premise that the Constitution was a compact among separate, sovereign states. The states, the argument ran, created the national government and granted it only the enumerated powers and those powers necessarily incidental to them. Indivisible sovereignty remained in the people of each of the states, and the national government was merely the agent of the associated states.

This premise supposedly led to several conclusions concerning the interpretation of the Constitution and the role of the states. ${ }^{8}$ One that is important for present purposes is that the states, as the parties to the constitutional compact, retained authority to determine what powers had been delegated to the federal government and what powers they had reserved. The corollary proposition was that the Supreme Court-an organ of the subordinate body, the federal government-lacked power to review state court judgments interpreting the Constitution. ${ }^{9}$

This issue vital to our federalism received decisive judicial settlement at an early stage. In 1816 the Court affirmed its power to review state court judgments involving federal questions. ${ }^{10}$ Repeated and successful assertions of the

${ }^{7}$ J. C. Calhoun, "Discourse on the Constitution and Government of the United States," in 1 Works of John C. Calhoun 238 (Crallé ed.).

${ }^{8}$ The principle of strict construction-resolving any doubts with respect to whether a particular power was given to the federal government in favor of the states-was a more influential conclusion. Most of the great constitutional controversies prior to the Civil War involved the question of implied powers. E.g., the establishment of a national bank, internal improvements, and the regulation of slavery in the territories.

${ }^{9}$ The lack of any express provision in the Constitution empowering the Supreme Court to review the judgments of state courts, and the absence of the practice of judicial review in a number of states were thought to support this position. An alternative argument, reasserted in the recent controversy over racial discrimination, was that a state could not be bound against its will by decisions reached by organs of the national government, but had a right to interpose its own views in refusing to honor those of the national government.

${ }^{10}$ Martin v. Hunter's Lessee, 1 Wheat. (U.S.) 304 (1816). In Marbury v. Madison, 1 Cranch (U.S.) 137 (1803), Chief Justice Marshall asserted the power to review acts of Congress. 
power, ${ }^{11}$ when viewed in the light of the Constitution, should have concluded all debate.

While there are some plausible arguments that judicial review of acts of Congress was not contemplated, ${ }^{12}$ it seems abundantly clear from the Constitution and the surrounding circumstances that Supreme Court review of state court judgments was intended. The Constitution extends federal jurisdiction to all cases arising under the Constitution, laws and treaties of the United States; and the supremacy clause has the effect of making the actions of the federal government, which includes the Supreme Court, supreme when acting within the field of its powers. Indeed, it is difficult to imagine a viable federal system without provision for final determinations of state power. As Justice Story said, in rejecting this challenge to the federal system: "From the very nature of things, the absolute right of decision, in the last resort, must rest somewhere."13

Moreover, history clearly indicates that the framers intended that the Supreme Court be given responsibility for umpiring the federal system. ${ }^{14}$ In the Constitutional Convention those favorable to a strong national government believed that a congressional negative on state legislation was necessary to control divisive tendencies in the states and to protect federal interests. On the other hand, those most hostile to a strong central government opposed a congressional veto and argued that the federal judiciary would adequately serve this function. The inclusion of broad judicial powers in Article III and the substitution of the supremacy clause for the congressional negative proposal was the final compromise. Section 25 of the Judiciary Act of 1789 merely implemented the intentions of the framers as expressed in the Constitutional Convention, ${ }^{15}$ the various state ratifying conventions ${ }^{16}$ and The Fed-

${ }^{11}$ See Cohens v. Virginia, 6 Wheat. (U.S.) 264 (1821) ; McCulloch v. Maryland, 4 Wheat. (U.S.) 316 (1819); Ableman v. Booth, 21 How. (U.S.) 506, 514-23 (1859); and Williams v. Bruffy, 102 U.S. 248 (1880).

${ }^{12}$ The arguments are fully elaborated in 2 W.W. Crosskey, Politics and the Constitution 938-1048 (1953).

${ }^{13}$ Martin v. Hunter's Lessee, 1 Wheat. (U.S.) 304, 345 (1816).

${ }^{14}$ The evidence is marshalled in J. Schmidhauser, The Supreme Court as Final Arbiter in Federal-State Relations 3-17 (1958).

${ }^{15}$ Id., at 7-13.

${ }^{16}$ For example, Oliver Ellsworth's statement in the Connecticut Ratifying Convention: "This Constitution defines the extent of the powers of the general government. If the general legislature should at any time overleap their limits, the judicial department is a constitutional check. ... On the other hand, if the states go beyond their limits, if they make a law which is a usurpation upon the general government ... independent judges will declare it to be so." 2 J. Elliot, Debates of the State Ratifying Conventions 196 (2d ed., 1854). 
eralist. ${ }^{17}$ The modern-day charge that the Supreme Court is guilty of "judicial usurpation" in reviewing state court judgments is without foundation and has been properly characterized as a "particularly persistent bit of political mythology."18

\section{The Responsibility of the Supreme Court for the Decline of State Power}

The charge that the Supreme Court's determination of constitutional questions has upset the constitutional balance and usurped the rights of the states has two aspects: first, that the Court has restricted the sphere of state authority by erroneous and improper interpretations of the constitutional prohibitions on the states; and second, that the Court has opened the floodgates to federal action by improperly broad interpretations of federal power.

Critics of particular doctrines which the Supreme Court accepts often indulge in the simplistic view that the Constitution is capable of exact application to any set of circumstances, however novel, and that all reasonable men would reach the same conclusions that they reach on any particular issue of constitutional interpertation. It is true that the basic framework of our federal system is presented with clarity in the Constitution. But many matters of principle, as well as detail, were unforeseen by the framers or deliberately phrased in ambiguous language. And the crucial provisions of the Constitution were couched in general terms susceptible of more than one reasonable interpretation. Thus the men who have occupied seats on our highest court are constantly presented with a choice of interpretive alternatives. Any assessment of the Court's performance as the umpire of our federal system must take into account these characteristics of our written Constitution.

The historic shifts in constitutional doctrine from period to period introduce an additional element of uncertainty. The Court of Roger Taney, for example, was more partial to the states' rights position than the Court of John Marshall. The existence of widely divergent judicial views concerning such basic matters as the powers of the federal government and the role of the states creates additional opportunities for judicial choice. Should a Justice presently sitting on the Court look for guidance to the words of John Marshall or Roger Taney? Harlan Stone or George Sutherland? It is no answer to say that precedent and tradition should be controlling-both provide ample opportunity for a judge to choose among permissible alternatives. In choosing a particular alternative, he may be moved by a desire to achieve logical symmetry in the legal system, by the desire to maintain continuity with the past, or by the desire to adapt the law to meet the novel circumstances which are

\footnotetext{
${ }^{17}$ The Federalist, No. 39 (Madison) and No. 80 (Hamilton) (Lodge ed., 1888).

${ }^{18}$ Schmidhauser, op. cit. supra note 14, at 16.
} 
constantly presented. ${ }^{10}$ The choice he makes is bound to be influenced to some degree by the impact of his social and economic philosophy on the particular facts under consideration.

A final factor influencing any evaluation of the Court's performance is one's conception of the significance of the Court in determining the long-run political structure of our country. It is true that the Court exercises important functions. But its role in interpreting the provisions of the Constitution which distribute governmental power between the nation and the states is usually greatly overemphasized. The character of judicial review prevents many important matters, such as unequal apportionment of congressional districts, ${ }^{20}$ from ever reaching the Court. Most vital matters of constitutional structure have been settled by the political process. One example of many is the crucial choice of the First Congress to act through separate federal instrumentalities rather than through state officials.

A glance at the attempts of the Court to settle controversies on which national sentiment was divided illustrates the Court's limited powers. The Court's participation in the slavery struggle ${ }^{21}$ was ineffective, harmful to the Court and the nation. The Income Tax decision, ${ }^{22}$ the Child Labor Case, ${ }^{23}$ and the struggle with the New Deal ${ }^{24}$ demonstrate the inability of the Court to settle vital issues of national life in a manner not accepted by a political majority. The moral is clear: the Court may act as a conservative board of review; it may delay for a matter of years measures which have widespread public support; but ultimately by change in personnel or through continued pressure the Court is responsive to dominant political opinion. Nor could it be otherwise in a nation which takes pride in the opportunities and responsibilities of democratic control. This process may do violence to the theory of an

${ }^{10}$ The last alternative was characterized by Cardozo as the method of sociology. B. N. Cardozo, The Nature of the Judicial Process 76 et seq. (1921). Critics of the Court have stated that this is a new approach. See, e.g., White, Construing the Constitution: The New "Sociological" Approach, 43 A.B.A.J. 1085 (1957). But similar techniques in constitutional interpretation and statutory construction have been used by state as well as federal judges from the earliest days.

${ }^{20}$ See Colegrove v. Green, 328 U.S. 549 (1946). Accord: South v. Peters, 339 U.S. 276 (1950) (county unit system in primary elections).

${ }^{n}$ Dred Scott v. Sandford, 19 How. (U.S.) 393 (1857). In other cases involving the burning issue of slavery, the Supreme Court displayed a healthy caution: Groves v. Slaughter, 15 Pet. (U.S.) 449 (1841); Rowan v. Runnels, 5 How. (U.S.) 134 (1847).

${ }^{22}$ Pollock v. Farmers' Loan \& Trust Co., 157 U.S. 429 (1895), judgment vacated on rehearing 158 U.S. 601 (1895). Overruled by U.S. Const., Amend. XVI.

${ }^{23}$ Hammer v. Dagenhart, 247 U.S. 251 (1918). Expressly overruled by United States v. Darby, 312 U.S. 100, 116-17 (1941).

* The major cases involving the scope of the commerce power are discussed in Stern, The Commerce Clause and the National Economy, 1933-1946, 59 Harv. L. Rev. 645, 883 (1046). 
immutable Constitution, but it doubtless was foreseen by the shrewd and realistic men who created an institution, independent in the respects they thought essential, but ultimately dependent upon other branches of government. $^{25}$

\section{A. RESTRICTIONS ON THE EXERCISE OF STATE POWER}

An essential feature of American federalism is that the states continued, under the Constitution, to exercise general governmental competence except to the extent that the Constitution or federal statutes deprived them of competence or displaced state law. Federal law, which emanates from the Constitution and from Congress, is built on and presupposes the existence of state law; it is the exception rather than the rule; and, generally, even where federal power to act is clear, the displacement of state law is thought to require some special justification. ${ }^{26}$

In performing its most essential function-the maintenance of a federal system by the enforcement of the constitutional prohibitions against state action - the Court by and large has respected these principles. For example, the Court's day-by-day job of enforcing the supremacy clause is largely a humdrum job of statutory interpretation involving little or no partiality toward the federal government. ${ }^{27}$ (Several important exceptions, such as the judicially implied limitation restraining the states from regulating certain interstate commerce, will be noted later.) Even in the few areas in which the federal courts have shouldered responsibility for the initial development of the law, such as maritime law, the overall impact on the exercise of state power is small. The general approval of the Court's performance in these areas is reflected by the lack of criticism: even the most ardent advocates of states' rights do not complain because the Supreme Court applies its own judicially created law to cases between states arising under the original jurisdiction of the Court! ${ }^{28}$ Nor, unfortunately, is the modern Court praised for retreating from a responsibility it should never have undertaken initially: the develop-

${ }^{25}$ A Court that is very far out of line with the temper of its time loses the moral respect of the people-ultimately, its only resource, since the Court has no coercive weapons at its command-and faces a hostile Congress. In any direct conflict, Congress has all the weapons: control of the size of the Court, control of its jurisdiction, and, if necessary, impeachment.

${ }^{20}$ An excellent treatment of the nature of federal law, to which $I$ am indebted, is Hart, The Relations Between State and Federal Law, 54 Col. L. Rev. 489 (1954).

${ }^{27}$ This is because the federal law which displaces state law in the governing of private activity is almost entirely statutory in character. The great bulk of the problems, therefore, are routine matters of statutory interpretation.

${ }^{28}$ See Connecticut v. Massachusetts, 282 U.S. 660 (1931), and Kentucky v. Indiana, 281 U.S. 163 (1930). A more deserving criticism might be based on the unwillingness of the Supreme Court in recent years to exercise its original jurisdiction. 
ment of federal rules of decision in diversity cases based on state-created rights, ${ }^{29}$

The Court's wise reluctance to undertake a supervisory role over the states on the basis of the provisions of Article IV evidences a similar restraint-a restraint all the more striking because the Article IV provisions were primarily intended to govern the relations of the states with one another. The explicit commands relating to fugitive slaves and extradition were muted by the refusal of northern states to return fugitives ${ }^{30}$ and the retaliatory refusal of southern states to deliver persons subject to extradition. ${ }^{31}$ The guarantee to every state of "a Republican Form of Government" was treated as a moral adjuration beyond the competence of the Court to deal with. ${ }^{32}$ Finally, problems arising under the full faith and credit clause have been handled with great delicacy so as not to foreclose a forum state from applying its own law to any controversy in which it has some interest. ${ }^{\mathbf{3 3}}$

Even with respect to those constitutional prohibitions providing protection from abusive state action to private individuals, the Court on the whole has performed a difficult assignment with wisdom and restraint. Many of the limitations of the original Constitution, such as the ex post facto clause and the contracts clause, were given at an early stage narrow interpretations which allowed the states to adjust to subsequent social and economic problems. ${ }^{34}$ And the Bill of Rights as a whole was held inapplicable to the states, either as an original proposition ${ }^{35}$ or by virtue of the Fourteenth Amendment. ${ }^{36}$ These

${ }^{20}$ See Erie R. Co. v. Tompkins, 304 U.S. 64 (1938), overruling Swift v. Tyson, 16 Pet. (U.S.) 1 (1842).

${ }^{80}$ See Prigg v. Pennsylvania, 16 Pet. (U.S.) 536 (1842), holding that the obligation to secure the return of fugitive slaves rested on the United States. The political difficulties in recovering fugitive slaves are discussed in $2 \mathrm{C}$. Warren, The Supreme Court in United States History 83-86, 258-78 (Rev. ed., 1926).

${ }^{\text {s1 }}$ See Kentucky v. Denison, 24 How. (U.S.) 66 (1861) (extradition provision not judicially enforceable).

s2 Luther v. Borden, 7 How. (U.S.) 1 (1849) ; Pacific States Tel. \& Tel. Co. v. Oregon, 223 U.S. 118 (1912); Ohio ex rel. Bryant v. Akron Metropolitan Park District, 281 U.S. 74, 80 (1930).

${ }^{3 s}$ See Currie, The Constitution and the Choice of Law: Governmental Interests and the Judicial Function, 26 U. of Chi. L. Rev. 9 (1958); Jackson, Full Faith and Credit-The Lawyer's Clause of the Constitution, 45 Col. L. Rev. 1 (1945).

st The ex post facto clause was held applicable only to penal laws, Calder v. Bull, 3 Dall. (U.S.) 386 (1798), in the form of statutory enactments, Frank v. Mangum, 237 U.S. 309, 344 (1915). Thus civil laws adversely affecting private rights are not restricted. But cf. 1 W. W. Crosskey, Politics and the Constitution 324-51 (1953). The contracts clause was interpreted as applying only to contracts previously formed. Odgen v. Saunders, 12 Wheat. (U.S.) 213 (1827). Again compare Crosskey's discussion of the intended meaning, 1 Politics and the Constitution 352-60.

25alder v. Bull, 3 Dall. (U.S.) 386 (1798).

${ }^{*}$ Adamson v. California, 332 U.S. 46 (1947); Palko v. Conecticut, 302 U.S. 319 (1937). 
large aspects of the Court's work cannot be overlooked in assessing its total performance.

There are other respects, however, in which the Court has imposed debatable, if not unjustifiable, restrictions on the exercise of state power. One of these is the operation of the commerce clause as a judicially enforced restriction on the exercise of state power-the so-called negative implications of the commerce clause. The Constitution does not, by express provision, make the regulation of commerce an exclusive national function. The natural inference, here as elsewhere, should be that the states retain general governmental power. Nevertheless, almost continuously from its adoption, the clause was thought to allow judicial attempts to preserve a national economy when Congress had not acted. By 1851 it was established that the commerce clause operated as an implied limitation upon state regulation of that commerce viewed by the Court as demanding a single uniform rule. ${ }^{37}$ The generality of the test had the effect of making the validity of state regulation depend in each case upon a judgment of the majority of the Court concerning the necessity or appropriateness of the challenged regulation, the local benefits to be secured, and the countervailing cost or inconvenience to the national economy. The present Court continues to exercise this established power, although it seems to accord more respect to state policy than did its predecessors. ${ }^{38}$

The Court's perforiance in a related area is even more deserving of criticism. In dealing with the question whether congressional legislation under the commerce clause has precluded state action, the Court in recent years has appeared to adopt a presumption in favor of federal "occupation of the field" and against state exercise of concurrent legislative power. ${ }^{39}$ Here again, the tests applied by the Court are so vague that judicial views as to the desirability of particular state regulatory schemes appear to be controlling. And the present Court apparently has a preference, not always shared by Congress, ${ }^{40}$ for uniform federal law. The recent extension of these vague tests to cases not involving the commerce power is disturbing. For example, in Pennsylvania v. $\mathrm{Nelson}^{41}$ the Court effected a broad displacement of state sedition laws with-

${ }^{87}$ Cooley v. Board of Wardens of Port of Philadelphia, 12 How. (U.S.) 299 (1852).

${ }^{2}$ See, e.g., Duckworth v. Arkansas, 312 U.S. 390 (1941).

${ }^{2}$ E.g., Guss v. Utah Labor Relations Board, 353 U.S. 1 (1957); Pennsylvania v. Nelson, 350 U.S. 497 (1956) ; H. P. Hood and Sons v. DuMond, 336 U.S. 525 (1949); Cloverleaf Butter Co. v. Patterson, 315 U.S. 148 (1942) ; Hines v. Davidowitz, 312 U.S. 52 (1941).

${ }^{2}$ During the period 1945-1957 alone the Supreme Court, after sustaining federal jurisdiction against claims that state power should prevail, was reversed by Congress in at least five instances. In only one case did Congress modify a judicial decision refusing to extend federal power at the expense of the states. Note, Congressional Reversal of Supreme Court Decisions: 1945-1957, 71 Harv. L. Rev. 1324, 1325 (1958).

435 U.S. 497 (1956). The Supreme Court has now retreated from the extreme position of the Nelson case. See Uphaus v. Wyman, 360 U.S. 72 (1959). 
out seriously considering the applicability of its commerce clause "tests of supersession" to a case involving overlapping criminal statutes and a congressional saving clause. Such cases significantly affect the federal-state balance. If a presumption is to be applied it should be that Congress, by its silence, does not intend to supersede overlapping state legislation. The states cannot remain as independent centers of governmental power if the expression of state policies is foreclosed merely by the enactment of not inconsistent federal legislation dealing with a similar matter.

The Fourteenth Amendment is another provision which has involved the Court in active policy-making harmful to the states. There is little doubt that the Amendment, which is still of uncertain meaning and ultimate significance, brought about a fundamental alteration in the federal system. Intended to ensure that the newly freed Negro was given equal treatment and the full rights of citizenship, the Amendment created broadly phrased rights capable of judicial enforcement and, in addition, appeared to give Congress extensive power to legislate in protection of civil rights. The Congress, after the fervor of the reconstruction period subsided, abandoned any effort to utilize its new powers; and the Court at first gave a narrow interpretation to the various Civil Rights Acts and declined to expand its review of state action claimed to violate the Amendment.

Then, in a startling burst of constitutional innovation, the Court, toward the end of the century, elaborated the due process clause as a substantive restriction on the exercise of state power. It is unnecessary to elaborate the doctrinal content of "substantive due process." 42 The important point for present purposes is that it destroyed the capacity of the states to deal with a substantial area of private economic relations at precisely the time when economic and technological developments were building great popular pressure for state regulation of economic activties. Frustrated by the Supreme Court, the people increasingly turned to the federal government for the effective handling of economic affairs. When substantive due process was finally dethroned in the process of the general "constitutional revolution" of the 1930 's, ${ }^{43}$ the habit of looking to Washington on many matters had become firmly established. Judged by its effects, the depredations on state power in the name of substantive due process must be ranked as the foremost encroachment by the Supreme Court on the rightful position of the states.

Curiously enough, the most vocal advocates of "states' rights" have not attacked the Court's former use of the due process clause to strike down state economic regulation. The attack, instead, is on the expanding role of the

\footnotetext{
62 The development and implications of the doctrine are stated in R. L. Mott, Due Process of Law (1926) and C. G. Haines, The Revival of Natural Law Concepts (1930).

${ }^{43}$ West Coast Hotel Co. v. Parrish, 300 U.S. 379 (1937), was the decisive case. See also Day-Brite Lighting, Inc. v. Missouri, 342 U.S. 421 (1952); Lincoln Union v. Northwestern Co., 335 U.S. 525 (1949); Olsen v. Nebraska, 313 U.S. 236 (1941).
} 
Court in policing the minimal decencies of civilized government. Of necessity, the latter assignment involves a large degree of discretion and is one of the most difficult-and creative-tasks of the Court. Under the leadership of Chief Justice Hughes, ${ }^{44}$ the Court began requiring a higher standard of the states in protecting civil and political rights-and the standard is still being raised. Few would agree with all of the Court's decisions involving personal freedoms, but it is unrealistic to view these largely procedural limitations as seriously curtailing state power. For the most part they merely put important limitations on the permissible ways of using the coercive powers of government. ${ }^{45}$ "Court enforcement of them may cut across time-honored policies and deeply felt beliefs. But they do not have the effect of transferring activities from one governmental level to another. Nor do they prevent either level from pursuing substantive programs of any kind likely to be adopted in this country." 46

In summary, on most matters related to the exercise of state power, the Court in recent years has been respectful and accommodating to state policy.

\section{B. LACK OF RESTRICTIONS ON NATIONAL POWER}

It is widely asserted that the Supreme Court has distorted the constitutional balance by abandoning its historic role of confining Congress within the limitations imposed by the Constitution. The argument is that the Court, by interpreting federal powers in an improperly broad fashion and by refusing to exercise its traditional power of review, has undermined the constitutional concept of a national government of limited powers and made the existence of state authority, even over matters of purely domestic concern, depend on the sufferance of Congress.

In its extreme form, this charge confuses judicial restraint with abdication. The Court has not denied its power to review acts of Congress but has become more selective about its exercise. The power is still there and different judges in different times may revive the now dormant doctrines of, for example, the Taft Court. Nor is it correct to say that the constitutional limitations on the Congress have disappeared. Recently, for example, the Court, invalidating an enactment authorizing an overseas trial for civilian dependents of the mili-

${ }^{4}$ See, e.g., Near v. Minnesota ex rel. Olson, 283 U.S. 697 (1931); De Jonge v. Oregon, 299 U.S. 353 (1937) ; Lovell v. City of Griffin, 303 U.S. 444 (1938). The development of the Court's in forma pauperis practice under Hughes has been traced in McElwain, The Business of the Supreme Court as Conducted by Chief Justice Hughes, 63 Harv. L. Rev. 5, 20-26 (1949).

${ }^{45}$ Even the School Segregation Case, 347 U.S. 483 (1954) and 349 U.S. 294 (1955), the most far-reaching application of the Fourteenth Amendment to protect civil liberties, does not displace the states from the operation of schools or the control of education. It merely limits in one respect the manner in which schools may be operated.

${ }^{40}$ This is the conclusion reached by the President's Commission on Intergovernmental Relations, A Report to the President for Transmittal to the Congress, at 31. 
tary, emphatically declared that the United States can never act except in a fashion consistent with the fundamental document. ${ }^{47}$

The mistaken impression that there are no limits to congressional action is largely due to the fortunate circumstance that Congress has not attempted to destroy the Constitution. If Congress purported to govern the descent and distribution of property or legislated with respect to land titles the Tenth Amendment would bar the way. Similarly, the Court would not allow Congress without a fight to destroy or cripple the independence of the states by directing their officers to perform federal functions inconsistent with their state duties. That these illustrations are improbable of enactment should hearten rather than discourage the friends of the states: No bevy of platonic guardians, to borrow Learned Hand's phrase, could maintain the constitutional division of power if the political safeguards of federalism failed and the people demanded a centralized state.

It cannot be denied, however, that the Supreme Court since 1937 has given congressional exercises of power a tolerant treatment. But the Court's decisions are not without support in the constitutional text and constitute, for the most part, a return to the nationalist views of John Marshall. The sanctioning of implied congressional powers and rejection of the extreme views based on the Tenth Amendment are illustrative.

The question of implied powers-whether the Tenth Amendment prevents the expansion of national power by virtue of the necessary and proper clause -was settled by the Marshall Court in $1819 .{ }^{48}$ The much less plausible argument underlying the Child Labor Case and its progeny ${ }^{49}$ - that the reserved powers of the states comprise an independent restriction on otherwise constitutional acts of the federal government-had little constitutional justification. The Tenth Amendment was declaratory of the division of powers between states and nation; it was not intended as a yardstick, or independent restriction, of federal power. ${ }^{50}$ Its sponsor, James Madison, put the matter quite clearly in 1791: "Interference with the power of the States was no constitu-

\footnotetext{
${ }^{47}$ Reid v. Covert, 354 U.S. 1 (1957). The holding of the majority was limited to trials for a capital offense. It should be noted that some of the fears underlying the Bricker Amendment are eliminated by Mr. Justice Black's forthright statement that exercise of the treaty power cannot override limitations contained in the Constitution.
}

${ }^{4}$ McCulloch v. Maryland, 4 Wheat. (U.S.) 316 (1819). Chief Justice Marshall there declared that the effect of the Tenth Amendment was to leave the question "whether the particular power which may become the subject of contest has been delegated to the one government, or prohibited to the other, to depend upon a fair construction of the whole instrument." Id., at 406.

๑ Hammer v. Datenhart, 247 U.S. 251 (1918) ; Bailey v. Drexel Furniture Co., 259 U.S. 20, 36, 38 (1922); Hill v. Wallace, 259 U.S. 44 (1922); Carter v. Carter Coal, 298 U.S. 238 (1936); and United States v. Butler, 297 U.S. 1 (1936).

${ }^{50}$ United States v. Darby, 312 U.S. 100, 124 (1941): “. . . the Tenth Amendment . . . states but a truism that all is retained which has not been surrendered." 
tional criterion of the power of Congress. If the power was not given, Congress could not exercise it; if given, they might exercise it, although it should interfere with the laws, or even the Constitutions of the States." 51 The modern Court's return to the earlier view of the Tenth Amendment did overthrow a number of precedents; but it was not without support in the great constitutional decisions of the formative era.

The Court's abandonment of substantive due process as a restriction on the exercise of both state and federal power was also sound. ${ }^{52}$ The free-wheeling discretion possible under this doctrine violated the democratic process at both levels of government and had the effect of immunizing a substantial area of private conduct from any governmental control. Surely it is incongruous for anyone respecting federalist values to criticize its demise, for its elimination terminated the most significant judicial inhibition on state power. States' rights, clearly, is the battle cry of those desiring no governmental action on a particular matter as much as the legitimate argument of those who cherish local responsibility.

Critics of the Court often take the somewhat inconsistent position of attacking any exercise of judgment by the Court as against the states but favoring an even broader judicial discretion as against Congress. They forget that the states are represented in the national legislature but that the federal government is not represented in equal fashion in the state legislatures. The need for some institutional protection of federal interests is apparent. On the other hand, the necessity for judicial control of the national government is not so great because of the existence of important political safeguards, in particular, the important role of the states in the composition and selection of the national government. ${ }^{53}$ Thus it can be argued that the Court would be justified in being more tolerant, rather than less, of federal legislation. Its more essential function is the preservation of the federal system through the enforcement of the constitutional limitations on state action. ${ }^{54}$

The expansion in the meaning of the commerce clause is perhaps more controversial. Yet even here the earliest interpretations of the clause, ${ }^{85}$ the re-

${ }^{51}$ II Annals of Congress 1897 (1791).

${ }^{52}$ For full discussion see R. H. Jackson, The Struggle for Judicial Supremacy (1941).

ss The allotment to each state of two Senators insures that the dominant political forces in each state are adequately represented in the Congress. State control over election qualifications and congressional districting has the effect of making state congressional delegations of much the same political complexion as the state legislatures. See Wechsler, The Political Safeguards of Federalism: The Role of the States in the Composition and Selection of the Natiunal Government, 54 Col. L. Rev 534 (1954).

"Mr. Justice Holmes made the point in 1913: "I do not think the United States would come to an end if we lost our power to declare an Act of Congress void. I do think the Union would be imperiled if we could not make that declaration as to the laws of the several States." O. W. Holmes, Jr., Collected Legal Papers 295-96 (1920).

${ }^{\infty}$ See Gibbons v. Ogden, 9 Wheat. (U.S.) 1, 189-92, 196-97 (1824). 
searches of modern scholars into its intended meaning, ${ }^{56}$ and the pressures resulting from a vastly changed economy ${ }^{57}$ provide arguments in support of the Court.

On the basis of the over-all record, I conclude that the Supreme Court is not responsible in any simple sense for the relative decline in state power. It is true that the Court has on occasion impaired the rightful position of the states in important respects. In most such instances, however, Congress has been left free to redress the balance, if the representatives of the states so choose. On the whole the Court has respected the constitutional division of powers and treated state policies with tolerance. National powers have been interpreted so as to be truly adequate to meet all national needs; but the judicial acquiescence in the development of national power has not yet placed the states in jeopardy.

\section{The Responsibility of the States}

In our federal system, both constitutional theory and political practice require that the initiative for central intervention come from the local constituencies which elect the national legislature. The inherent tendency is to restrain and retard the expansion of federal activities into areas previously handled by the states. Thus central intervention only occurs when the people of the several states demand it. The march of power to Washington has not been the result of Supreme Court decisions nor of the communist conspiracy, but of popular pressure. At every step a Congress fully responsive to state interests has enacted the measures and appropriated the necessary funds.

It is unrealistic to suppose that there is any easy solution to the attrition of state power. The giant forces which have caused the growth of federal power are too strong. Foremost of these is the world situation in which we find ourselves. As long as the risk of war remains high, the awesome responsibilities of national defense and of a global foreign policy may be expected to generate constant pressure for further expansions of federal activity. The accelerating pace of technological changes also presents grave problems for the continuance of federalism. The development of economical atomic power, for example, may oust the states from the regulation of public utilities. Other technological and economic developments are bound to create pressure for uniform national treatment. Finally, the increasing appetite of the American people for minimum national standards obtainable only through federal legislation may result in further inroads upon state authority. The demand for minimum national standards has already led to social security, a minimum wage, and national responsibility for the prevention and cure of economic depressions.

${ }^{50}$ See 1 W. W. Crosskey, Politics and the Constitution 17-294 (1953).

${ }^{67}$ See Stern, The Commerce Clause and the National Economy, 1933-1946, 59 Harv. L. Rev. 645, 883 (1946). 
And proposals for widespread federal participation in the fields of health and education are even now receiving serious attention.

The signs of approaching danger are apparent. As Leonard White has said, ". . . if present trends continue for another quarter century, the states may be left hollow shells, operating primarily as the field districts of federal departments and dependent upon the federal treasury for their support." 58 For those who believe, as I do, that the values of federalism are enduring and that federalism is as necessary to liberty now as it ever has been, the path of prudence lies in the strengthening of the initiative and responsibility of selfgoverning, local democracy. Castigation of the Supreme Court is unlikely to reverse the tide which has set in against the states. The relative decline in state power vis-à-vis the power of the national government can be halted only by vigilant and responsible state governments undertaking the manifold tasks which have gone or are going to the federal government by default. Above and beyond the relative decline of state power, the absolute growth in the power of the national government remains a peril for the survival of federalism. The Supreme Court cannot be expected to play a vital role in preserving federalism - the diffusion of power among various units of government-from the longrun effects of expanding national power. For this larger problem, only the willingness of the electorate to leave a significant role to private voluntary activity can provide a solution.

${ }^{58}$ L. D. White, The States and the Nation 3 (1953). 